Tatjana Jukić

Faculty of Humanities and Social Sciences

University of Zagreb

\title{
An Austro-Hungarian America: Emerson for Croatia, 1904-5
}

It was principally through Antun Gustav Matoš (1873-1914) that Croatian literature received its modernity for the twentieth century, as well as its sense of Europeanness. His essay on Emerson (1904-5) can be analyzed as part of the same agenda, especially in view of its marked Nietzschean overtones; it is Nietzsche's Emerson that Matoš brings to Croatian culture and, with it, a corresponding inflection of both Europe and philosophy. While this suggests that a Nietzschean America comes to shape the American phantasm for twentieth-century Croatian modernity, I propose to discuss another operation which is equally critical to this placement of Emerson: the way in which Austro-Hungarian cultural practices, definitive to Croatia at the time and at work in Matoš, decide Emerson's profile and refract some of its Nietzschean features.

Key words: America, Austria-Hungary, Antun Gustav Matoš, Ralph Waldo Emerson, Friedrich Nietzsche

It was principally through Antun Gustav Matoš that Croatian literature received its modernity for the twentieth century, as well as its sense of Europeanness. ${ }^{1}$ In 1904 and 1905, while living in Paris, he published two versions of an essay on Emerson, one in Serbia and one in Croatia: two years, he writes, after North America, along with the rest of the world, celebrated the centenary of Emerson's birth. This, however, is not to say that he writes "post festum,

1 A slightly different version of this essay was published in Croatian as "Matošev Emerson, ili konzekvencije flanerizma" in Mjesto, granica, identitet. Prostor u hrvatskoj književnosti i kulturi (ed. Lana Molvarec), Zagrebačka slavistička škola, Zagreb, 2014, 67-80. All translations from Matoš are mine. 
after the fact, because writing about minds like that is never too late or too early" (Matoš 1973: 41).

This is evidently of critical interest to Matoš, because he opens the essay with the above remark: he begins by emphasizing that both he and Emerson are figures of a certain counter-historical contemporaneity, of untimeliness. It is here already that Matošs approach to Emerson is reminiscent of Nietzsche, especially of his Untimely Meditations (Unzeitgemässe Betrachtungen). In Untimely Meditations, time is not that of history or of historicizing. It is untimely specifically where it imparts a sense of contemporaneity, a sense of time in layers and from within faultlines, a time-with, time which is plural to begin with, time inconceivable without an addition or else from within an addition. After all, Matoš invokes Nietzsche explicitly when he says that no nineteenth-century scholar is so "menschlicher, allzumenschlicher" as Emerson (1973: 41).

This in turn reflects the position of critical importance to Nietzsche himself, because Nietzsche too privileges Emerson as a scene of instruction. Untimely Meditations is a case in point here, especially the essay "Schopenhauer as Educator" ("Schopenhauer als Erzieher"). Nietzsche, that is, foregrounds Schopenhauer as educator of culture and philosophy, but is given to quoting from Emerson in the most critical of positions - especially from "Circles." One could therefore argue that Emerson is the true educator of culture and philosophy in Nietzsche, as well as the figure of the very untimeliness which to Nietzsche is constituent. ${ }^{2}$

Matoš imagines Emerson as an expanse of thought which does not allow for homogenizing. Consequently, it is the thought itself of expanse and expansion: it is the thought which is defined by mobilization, movement and spreading out. According to Matoš, "Emerson is not to be forced into any of the schools of philosophy" and "one could not imagine spirits more differ-

2 In his 1910 essay on Nietzsche, Matoš insists that Emerson was of critical importance to the German philosopher and claims that reading Emerson was instrumental to Nietzsche's recovery "from melancholia" in 1874: it was at that time, Matoš emphasizes, that Nietzsche completed "Schopenhauer as Educator" (1973: 110). 
ent than Emerson is from Hegel"; it is "for this very reason that the scholar from Concord is the program of the young America" (1973: 42-43). This is also why Matoš insists that Emersonian thought is wide and universal, precisely where it is not original or systematic. In other words, it is the kind of thought, or rather the type of rationality, which demands that universality be approached in terms of microphysics, as a kind of capillary motion. One could almost say that Emerson in Matoš is to map out a position where mathematism is to give way to microphysics, also where metaphor is to give way to metonymy. In turn, microphysics and metonymy are to be seen not merely as an indication of universality, but - surprisingly perhaps - as an indication of the very logic of universalism.

As a result, America emerges in Matoš as a scene of this metonymic rationality, of microphysics, of mobilization at its purest. At the same time, this is to say that America makes sense as a scene of universalism, or else that America makes no sense if not as a scene of universalism. It is in this way that Matoš's Emerson points in fact to America as imagined and constituted by its founding fathers, primarily by Thomas Jefferson. I would like to quote from Hannah Arendt, who claims that the very idea of America depends on the Jeffersonian accent on the new continent and the new man. According to Arendt, the new continent is what it takes for the new man, because the new continent secures the unrestrained freedom of movement, a kind of unconditional mobility (2006: 14-15). Arendt privileges this mobility; indeed, it is in this unconditional mobility that she situates the raison itself of the American Revolution: not merely its reason, but also the rationality specific to it. What is more, Arendt claims that this is why European revolutions never quite came close to the conceptual purity of the American revolutionary blueprint: because no continental revolution ever relinquished the notion of the nation-state. One could propose, therefore, that Arendt's perspective on the Jeffersonian accent reads in fact as a study of metonymy, with metonymy as the logic of the revolution, as well as the logic of the very political project of America.

In Matoš, what defines Emerson as truly American is precisely the re- 
lation which he forges between freedom and movement, freedom as movement. According to Matoš, there is "something free" in Emerson, something "unrestrained and truly American" (1973: 41). This therefore constitutes the truth of America, an American truth, a truth which one cannot approach in any other way or position. Which is then also how Matoš maps out the position where Jeffersonian America, as a political project, is to become the privileged destination of philosophy.

Also - it is not so much that there is something free in Emerson but that Emerson has that something which is free, unrestrained and truly American. "Nešto slobodno, nevezano i doista amerikansko ima taj pisac," writes Matoš (1973: 41, emphasis mine). Having that something which is free, unrestrained and truly American secures Emerson as a scholar, although it evidently cannot secure his subjectivity - only his labor, the labor of thought. It is the kind of labor which appears to imperil the maintenance of subjectivity, or else subjectivity perceived in terms of maintenance. So there is a political economy to Emerson which is not to be separated from psychic economy; it is a small wonder that Stanley Cavell, for instance, tends to analyze Emerson alongside Freud and psychoanalysis. If this means that an American scholar, or an American economist, or simply an American, is more or less insane, Emerson - as quoted in Matoš - replies that whoever lives for gain alone is a beggar (1973: 43). In the wake of this thought, Matoš quotes two more sentences from Emerson, now also as a kind of instruction for understanding Croatia, in Austria-Hungary, in 1905. The first one is that the interest of history lies in the destiny of the poor. The second is that, similarly to Ruskin and Tolstoy later, Emerson thought that people, scholars included, are incomplete unless well acquainted with craftsmanship and economy (1973: 43).

Cavell sheds light on this proposition in Pursuits of Happiness, when he analyzes the luxury and leisure of the Hollywood comedies produced in the 1930s, during the Great Depression. According to Cavell, Emerson best explains how luxury in these comedies should be grasped, the line of reasoning to be found in his essay "History": "It is remarkable that involuntarily we always read as superior beings... We honor the rich because they have 
externally the freedom, power and grace which we feel to be proper to man, proper to us. So all that is said of the wise man by Stoic or Oriental or modern essayist, describes his unattained but attainable self" (Cavell 1981:5).

This is the context in which to interpret a strong claim that Matoš makes in his 1904 essay on Andrew Carnegie, the American industrialist and philanthropist (and another essay where Emerson features as a thinker important to Matoš). Matoš thinks highly of Carnegie and champions him as the role model for Croatia. Yet he critiques Carnegie's statement that the cause of the downfall of great nations is not hardship and poverty but luxury and corruption. In Croatia, we know how to be both destitute and corrupt, and the corrupt poor are worse by far than the corrupt rich, says Matoš in the conclusion of his essay (1973: 40).

While the above sentence may read as rash and callous, it actually contains a suggestion similar to the one that Cavell detects in Emerson: that the poor are corrupt when they accept wealth as a value in itself, instead of seeing it as but a tool of political pedagogy, or else as a tool for working toward an unattained but attainable self (which Cavell proceeds to identify as moral perfectionism). ${ }^{3}$ It is in this light that one should understand the most critical sentence of Matošs Emerson: "One day we will learn how to replace politics with education" (1973: 43). ${ }^{4}$

Croatia here is evidently symptomatic of Austria-Hungary, of which it was part at the time: because Carnegie as quoted by Matoš speaks about the downfall of great countries. Austria-Hungary is in this way compared to America, with America as a scene of instruction for Austria-Hungary. While this too may seem unexpected, particularly in view of the fact that Austria-Hungary was a monarchy and the United States a republic, so that their very constitutions appear to be beyond comparison, the comparison

\footnotetext{
3 See also Cavell 1988.

4 Matoš uses the word odgoj in the above sentence to indicate education, pedagogy and upbringing alike. However, seeing that he translated Nietzsche's "Schopenhauer as Educator" as "Schopenhauer kao odgojitelj" (1973: 110), I have decided to translate his odgoj here as education.
} 
nevertheless reveals important facets of both. Austria-Hungary, that is, was indeed of a specific political constitution, insofar as it was founded in 1867 as a so called personal union of the dual monarchy of Austria and Hungary: it was a relatively loose political collective which at all times kept negotiating the very grounds of collectivity and collectability. One could say that Austria-Hungary was indeed a great country, but only thanks to the fact that it kept questioning the very reason of the state - raison d'État - as well as its conditions. Similarly, it was not until after the Civil War that the United States of America gave way to significant centralization; it was only with the Lincoln administration that the States themselves were no longer a relatively loose political collective. As a result, raison d'État in Austria-Hungary was markedly divorced from a unified imaginary of territory or territoriality, now as a kind of pure reason of the state which occupies an empty place, a no-place, a position which is assigned to metaphor and comparable to where psychoanalysis situates the law. In turn, the idea of territory and territoriality in Austria-Hungary, thus exempted from metaphor, persisted in the imaginary one could associate with metonymy, capillarity and microphysics. So, while the reason of the state, as well as the law, was decided in the domain of metaphor (with Kafka's narratives as a case in point), the idea of territory in Austria-Hungary remained singularly encumbered with a kind of metonymic surplus, which was promising to mobilize and revolutionize the body politic precisely to the extent to which metonymy does not share its constitution with metaphor, law and the reason of the state. This then is the position from where to grasp the fact that both Matoš and, later, Miroslav Krleža privilege the peasantry, as collectives attached to locality and territoriality, to indicate the revolutionary potential: this always happens where metonymy represents the peasants better than metaphor and where metaphor perhaps cannot represent the peasants to begin with.

It is certainly symptomatic that Matoš's and Krleža's representations of Croatian peasants in Austria-Hungary correspond to how Viktor Tausk, Freud's disciple and the military doctor in the First World War, describes the peasant recruits. According to Tausk, peasants in the Austrian-Hungarian 
Army are incompatible with military discipline, which is based on an absolute, pure value of command and authority divorced from the idea of locality; peasants, on the other hand, cling to the imaginary of locality and territoriality. ${ }^{5}$ Symptomatically, Tausk describes the peasants as somewhat impervious to psychoanalysis, too, which suggests that the authority fundamental to the Austrian-Hungarian Army (in the conditions of a world war) corresponds to how psychoanalysis imagines the symbolic sphere (of law and language). Finally, Tausk's remarks correspond to how Karl Marx analyzes peasants in "The Eighteenth Brumaire of Louis Napoleon": Marx excludes the peasants from political self-representation, arguing that they cannot represent themselves. ${ }^{6}$ If this suggests that there may be a flaw in Marx's thinking of the revolution (since most of the successful communist revolutions in the twentieth century took place in predominantly agricultural societies - Russia, Yugoslavia, China, Cuba, Vietnam...), it equally suggests that Marx, like Tausk, excludes peasants from the domain of metaphor and from the metaphoric principle.

Insofar as Marx's flaw in thinking the revolution concerns his elision of the peasantry, it also suggests that Marx failed to take into account, fully, the lesson of the American Revolution, specifically its raison, which was deeply impressed by Jefferson's constitutional appreciation of agriculture and by what was Lucretian and Epicurean about this appreciation. In other words, Marx's flaw should be located not merely in his shedding of peasants but equally in his failure to understand Jefferson; a failure all the more telling in view of the fact that Marx formed as a philosopher in an elaborate account of the Epicurean reworking of Democritus' physics - precisely the match for what is unmistakably Lucretian in Jefferson's political logic. ${ }^{7}$ It is almost as if

\section{See Tausk 1991: 158, 160-161.}

6 See Marx 1960: 198-199. Among other things, in these paragraphs Marx compares peasants to a sack of potatoes: an image which implies that peasant collectives are constituted around metonymic relations. Its derogatory angle suggests that Marx critiques precisely the metonymic character of these collectives or else metonymy as the apparatus of political reasoning.

7 The title of Marx's doctoral dissertation was Differenz der demokritischen und epi- 
Marx had somewhat repressed his own Epicurean beginnings when he later embarked on his critique of the political economy of capitalism, a repression whose impact on his theorizing of revolution would turn out to be truly Oedipal. In turn, this American dimension of revolution keeps surfacing in the Austro-Hungarian imaginary, particularly aptly in Matoš's discussion of Emerson, for instance. After all, Gilles Deleuze also singles out the American and the Austro-Hungarian imaginaries as peculiarly revolutionary, thereby implying an unacknowledged (philosophical?) affinity of the two. ${ }^{8}$ This is an affinity which could be traced perhaps to a common interest in physics (of classical antiquity), rather than to mathematics; what ensues is a specific thinking of universalism based in metonymy, not metaphor. ${ }^{9}$

So there is a logic to the Austro-Hungarian imaginary which sits well with Jeffersonian and Emersonian America; finally, the political cultures in both depend on a rather fundamental tension between law and contract. Furthermore, Austria-Hungary forms in 1867 as a relatively loose political collective just as other German countries are unifying and homogenizing. Austria-Hungary remains outside of this process of unification and homogenization, only to deconstruct its Germanicity into a script of minoritarianism. It is a Deleuzian minoritarianism: what is important is not so much the fact that Austria-Hungary was characterized by a large number of so-called small or minor languages in opposition to German, but rather that German persisted in Austria-Hungary in the zones of indeterminacy and undecidability so that ultimately any single, pure language was to be perceived as foreign. ${ }^{10}$

kureischen Naturphilosophie. See Dolar 2014 for a detailed reading of Marx's dissertation, especially in relation to Hegel.

8 For privileging the American and the Austro-Hungarian imaginaries as peculiarly revolutionary, see Deleuze 1967 and 1996: 47-91.

9 This, in part at least, explains also Matošs decision to pair his Emerson with Rousseau. While writing on Emerson, he quotes from Rousseau that it is in the country that we learn how to love and serve humanity - in cities, however, we learn only how to hate it (1973: 42).

10 Hence Deleuze's continued interest in Kafka. Matoš, too, wrote also in German and published in Agramer Tagblatt, a Zagreb-based German newspaper. 
Also, it is the homogenizing unification of the German lands that Nietzsche critiques in "Schopenhauer as Educator," when he adopts Emerson's description of revolutionary culture in order to argue that revolutionary culture is an alternative to the kind of subjectivity which is befitting the politics of homogenization. According to Emerson, "a new degree of culture would instantly revolutionize the entire system of human pursuits" (1950: 284). ${ }^{11}$ True, Matoš too adopts Emerson as instruction, now for Croatia in Austria-Hungary. Still, while Matoš needs Emerson so as to suggest that Croatia is a pre-revolutionary or perhaps a proto-revolutionary culture, Nietzsche employs Emerson in order to show that the homogenized Germany of the 1870s lost its revolutionary potential or, more precisely, to show that foregoing the revolutionary potential was the price Germany paid for its homogenization.

If this is how Matoš provokes ultimately a comprehensive comparison of the American and the French Revolutions, what is truly provocative about his perspective is its implicit rejection of Nietzsche's positions. Nietzsche, that is, seems to be implying that the Emersonian agenda is not universalist, insofar as not all can open up to revolutionary becoming; some respond to it by developing structures comparable to those which Freud will later describe as masochism. Matoš, on the other hand, registers no such restriction. Instead, he is emphatic about embracing Emerson's idea of politics as education, as if suggesting that crisis implicit in it is also how to think universalism. It is almost as if Matoš suggests that Nietzsche needs to be sidestepped if one is to understand America (and Emerson), as well as the event of the revolution where revolution is definitive to politics in modernity. Which is where another discussion can begin, and in the same vein: that of Derrida's rejection of Jefferson in favor of Nietzsche, in his famous refusal to address the American Declaration of Independence except in the form of an excuse. ${ }^{12}$

11 In Nietzsche: "Ein neuer Grad der Kultur würde augenblicklich das ganze System menschlicher Bestrebungen einer Umwälzung unterwerfen” (1988: 426, emphasis F. N.). Cavell pays special attention to this quote from Emerson in Nietzsche when discussing what he calls "the constitution of Emersonian perfectionism." See Cavell 1988: 10.

12 See Derrida 1986. 


\section{Works Cited}

Arendt, Hannah. On Revolution. New York: Penguin, 2006.

Cavell, Stanley. Pursuits of Happiness. The Hollywood Comedy of Remarriage. Cambridge (Mass.), London: Harvard UP, 1981.

--- . Conditions Handsome and Unhandsome. The Constitution of Emersonian Perfectionism. Chicago, London: The U of Chicago P, 1988.

Deleuze, Gilles. Présentation de Sacher-Masoch. Le Froid et le cruel. Paris: Éditions de Minuit, 1967.

Deleuze, Gilles and Claire Parnet. Dialogues. Paris: Flammarion, 1996.

Derrida, Jacques. "Declarations of Independence" (trans. Tom Keenan and Tom Pepper). New Political Science 7. 1 (1986): 7-15.

Dolar, Mladen. "Marx’s Clinamen." Manuscript, 2014.

Emerson, Ralph Waldo. The Complete Essays and Other Writings of Ralph Waldo Emerson. Ed. Brooks Atkinson. New York: Random House, 1950.

Marx, Karl. Der achtzehnte Brumaire des Louis Bonaparte. Karl Marx/Friedrich Engels - Werke. Band 8. Berlin: Dietz Verlag, 1960.

Matoš, Antun Gustav. O stranim književnostima. Sabrana djela Antuna Gustava

Matoša. Svezak IX. Ur. Vida Flaker. Zagreb: Jugoslavenska akademija znanosti i umjetnosti, Liber, Mladost, 1973.

Nietzsche, Friedrich. Die Geburt die Tragödie. Unzeitgemäße Betrachtungen I-IV.

Nachgelassene Schriften 1870-1873. Eds. Giorgio Colli and Mazzino Montinari. Berlin: De Gruyter, 1988.

Tausk, Viktor. Sexuality, War and Schizophrenia. Collected Psychoanalytic Papers. Ed. Paul Roazen. New Brunswick, London: Transaction Publishers, 1991. 